DOI: https://doi.org/10.34069/AI/2021.45.09.24

How to Cite:

Minyar-Beloroucheva, A., \& Sergienko, P. (2021). Linguistic approach to axiological particularities of PR discourse study as an interdisciplinary field. Amazonia Investiga, 10(45), 242-251. https://doi.org/10.34069/AI/2021.45.09.24

\title{
Linguistic approach to axiological particularities of PR discourse study as an interdisciplinary field
}

\section{Аксиологический подход к изучению лингвистических особенностей РR дискурса как междисциплинарной области}

Received: July 21, 2021

Recived: Jus 21,2021

Accepted: September 30, 2021

\begin{abstract}
The topicality of this research is explained by the increased interest in public relations (PR) discourse as a response to the challenges of the present. The main objective of the research is linguistic study of PR discourse from the standpoint of interdisciplinarity. It is important to examine not only the peculiarities of PR pragmatics aimed at achieving the hearts of people, but also the linguistic means employed by PR managers in their practice to influence and control public opinion. Linguocultural research as part of an interdisciplinary approach to PR discourse implies its anthropocentriccommunicative interpretation to carry out an integral linguistic analysis of PR discourse that forms its interdisciplinary core as well as its genre-stylistic particularity. The results and discussion given in the body of the article show that PR is a three-faceted entity, including the professional communication, multi-disciplinarity of knowledge required for PR experts as well as professional tools and skills. Linguistic expression of axiological aspect of PR discourse dealing with companies' positive reputation is given special attention in this paper. The authors come to the conclusion that interdisciplinary knowledge transfer is of growing demand as it enriches the theoretical and practical spheres of human activity.
\end{abstract}

\begin{abstract}
Аннотация
В рамках междисциплинарных исследований, находящихся в центре внимания современной лингвистики, используются различные подходы и тенденции для понимания рассматриваемого предмета. Настоящая статья посвящена изучению дискурса по связям с общественностью (PR), который по своей сути является междисциплинарной областью. Актуальность данного исследования объясняется возросшим интересом к PR-дискурсу. Новизна статьи заключается в том, что впервые PR-дискурс исследуется как междисциплинарный объект. В задачи PR входит создание положительного имиджа компании и ее продуктов или услуг в сознании потребителей, которое достигается благодаря языковым средствам, используемым PR-специалистами в своей практике для влияния и контроля общественного мнения. Лингвокультурологические исследования в рамках междисциплинарного подхода к PRдискурсу предполагают его антропоцентрическую коммуникативную интерпретацию для проведения комплексного анализа. Лингвистические особенности PR-дискурса формируют не только его жанрово-стилистическую специфику, но и его междисциплинарное ядро. В результате исследования было установлено, что PR - это многогранная область, включающая профессиональную коммуникацию, междисциплинарность знаний, а также профессиональные умения и
\end{abstract}

\footnotetext{
$96 \mathrm{PhD}$ in Linguistics, Dr. Habil, Professor Lomonosov Moscow State University, Russia.

${ }^{97} \mathrm{PhD}$ in Linguistics Lomonosov Moscow State University, Russia.
} 


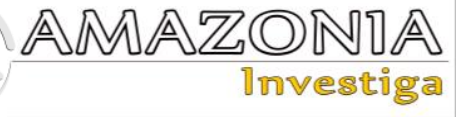

Keywords: axiology, discourse, interdisciplinarity, linguistics, PR.

инструментарий. В данной статье особое внимание уделяется лингвистическому выражению аксиологического аспекта PRдискурса, необходимого для создания положительной репутации компаний. В заключении отмечается, что междисциплинарность, являющаяся средством передачи современного знания, становится все более востребованной, поскольку она обогащает теоретическую и практическую сферы деятельности человека.

Ключевые слова: аксиология, дискурс, лингвистика, междисциплинарность, PR.

\section{Introduction}

Modern world is noted for a variety of forms and methods of public relations (PR) activities. Generally defined as a managerial practice or 'a strategic communication process that builds mutually beneficial relationships between organizations and their publics' (PRSA, URL). In other words, the aim of public relations communication process is to establish a positive relation with other companies and their target audience. PR attempts to create and maintain positive reputation of a business company or an individual, thus endowing communication practice with high relevance for the sustainable success of the company. At present, at the time of the Fourth Industrial Revolution the world has drastically changed. The transformation is perceived in every aspect of human life and activities as well as in the development of scientific thought. Regarding the sphere of public relations, the production of material and spiritual values can be completed only with respect to the latest achievements in arts and sciences.

The present research is devoted to studying linguistic particularities of PR discourse, especially to its axiological aspect, which permits a holistic interdisciplinary view over the field of public relations. The relevance of this study is determined by the increase of PR role in the present globalizing world. The objective of the research is to demonstrate the interdisciplinarity of PR as a nascent discipline with a special attention to linguistic realization of the pragmatic goals. The material for the study was taken from PR press releases issued by large international companies. Research methods including philological analysis, synthesis and generalization contributed to the performing of such research tasks as establishing the role of axiological means of linguistic expression and their part in creation of persuasive texts. The results of the study have allowed for the possibility of showing the interdisciplinary nature of PR discourse, which is achieved by linguistic means and stylistic devices, with a great attention paid to the axiological aspect. The conclusions prove that PR undergraduates should be well educated and knowledgeable in different fields of human activities, arts and sciences to face in the proper way the challenges of the day. The practical significance of the study provide for the possibility of using its results in teaching PR undergraduates to understand PR pressreleases of the companies and write their own PR press-releases.

Despite vast literature devoted to the theory and practice of PR, its discourse has not been studied from the prism of interdisciplinary approach which is a characteristic feature of research at the dawn of the digital age, as it unites scientific knowledge and technological advance for the benefit and worldview of the researchers. Although the interdisciplinary study is at the nascent stage of the theoretical development, some achievements in the practical sphere have already been marked for the further development of PR discourse. This enables researchers to navigate and interpret the modern trends of professional PR discourse development within the practical and theoretical insights.

\section{Literature Review}

The shaping of Public Relations commenced almost a century ago, when the book by E. Bernays entitled "Crystallizing public opinion” (Bernays, 1923) came out. It was a springboard for the further development of the whole public relations industry. A new turn occurred in 1948 when international PR organizations were formed and conferences were held. Among the founders of professional PR organizations was Dr. Rex Harlow, who 
summarized in 1976 various prior attempts to define the professional field of activity: 'Public relations is a distinctive management function, which helps establish and maintain mutual lines of communication, understanding, acceptance and cooperation between an organization and its publics; involves the management of problems or issues; helps management to keep informed on and responsive to public opinion; defines and emphasized the responsibility of management to serve the public interest; helps management keep abreast of and effectively utilize change, serving as an early warning system to help anticipate trends; and uses research and sound ethical communication as its principal tools' (Harlow, 1976: 36). It should also be mentioned that later on this definition was expanded and specified with the aim to single out certain characteristics pertaining to the profession. What is more, together with different definitions various attitutes to the professional activily can also be revealed. Thus, some theorists see $\mathrm{PR}$ as a benevolent practice, vital for the society assisting the people to be conversant in this complicated world (Grunig, 1984; Black, 1989).

Since that time numerous conferences have been organized with the aim to work out theoretical and practical principles of PR as a practical activity and PR as an educational discipline. It was also introduced into curricula of universities worldwide. (Berger, 2011; Wolstenholme, 2013, Sergienko et al., 2021). It is important to note that, the first national standard of PR education was adopted in the United States in 1975. Later on, the International PR Association (IPRA), founded in 1955, attempted to systematize the international legacy concerning PR education in 1980 to work out methods and methodology of teaching PR undergraduates. It was established that PR should be taught as an interdisciplinary subject with regard to theory and practice of the discipline. Sam Black in his famous 'Wheel of PR Education' suggested one of the widely accepted models of PR education which has been applied (IPRA Goldpapers, 1982; MinyarBeloroucheva et al, 2020).

In the light of linguistics, it is necessary to distinguish the professional sphere of public relations possessing its own discourse, which can be defined as the message transmission aimed at informing both public and members of different organizations about something to develop twoway communication in society to organize and maintain social harmony (Kubryakova, 1981; Vishnyakova et al., 2020).
The process of unification of the world that occurs in society provides the creation of the worldview, necessary to put into effect the achievement of arts and sciences as a unified system. Moreover, relentless challenges facing the humanity are so acute for global society, that the issues posed before it, demand a holistic approach, presupposing perceptions of various scientific positions and philosophical standpoints. Thus, the paradigm shift is obvious as a segmented study of every discipline is being substituted with a comprehensive interdisciplinary approach to the problem for the sake of generating a global vision. In other words, the logical stage in human development demands transdisciplinarity, which refers to research that helps eliminating the gap between scientific knowledge and the knowledge of society as 'an integral component of innovation and problem solving strategies in the life-world' (Hoffmann-Riem et al, 2008: 17; Guerreiro, 2016).

"Interdisciplinary turn" in scientific research was equal to revolution in science and technology, because unlike the disintegration of sciences and disciplines of modern times, post-modernism was veering to integration of arts and sciences into a unique whole. That is why there has been a tendency to merge all the previously disintegrated fields of intellectual knowledge, heirs to the $17^{\text {th }}$ century development of scientific thought. Integration of sciences breaks disciplinary boundaries reflecting the universal tendency to unification of humanity at every level of its existence including political, economic, cultural and social aspects. At present it is generally accepted that 'social change cannot be interpreted in a particular social science, but must be understood in the social and natural whole of human life' (Jessop and Sum, 2001). The process of integration is a long one, and it occurs stage by stage, the first stage being transdisciplinarity (Fairclough, 2000) or 'postdisciplinary' (Jessop and Sum, 2001). Thus, some prominent scholars suggest transcending disciplinary boundaries in Critical Discourse Analysis (CDA) (Weiss \& Wodak, 2003, pp. 110-111), which is also regarded as a characteristic feature of contemporary research in most social sciences, including the sphere of PR discourse.

Theorists resorting to the interdisciplinary approach to PR discourse profit from the expansion of the knowledge system of different fields of knowledge. The holistic character of PR activity needs the integration of different scientists and disciplines, including sociology, 


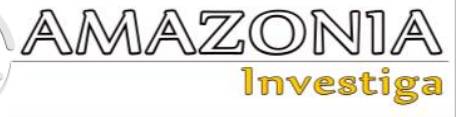

psychology, linguistics, Mass Media, pragmatics, ecology, law, political science. Among the main representatives of such an approach are several theorists and practitioners (Adolphsen, 2014; Petrov \& Wilson, 2016; Tanji, \& Broudy, 2017; Heaney \& Rebolini, 2017; Rosenberg, 2021; Stahl, 2018).

\section{Methodology}

The result of the above-described state of affairs is the emergence of a number of complex interdisciplinary studies in different fields of knowledge. Interdisciplinary approach has been adopted as a necessary prerequisite for understanding the complexity of professional PR practice. General scientific methods of analysis, synthesis, comparison and generalization are used alongside philological, etymological and textual analyses. For the all-encompassing research in the sphere of PR discourse researchers resort to the methods of data analysis, psychology, cultural studies, sociolinguistics and cognitive linguistics. All in all, researching and analyzing data is key to the professional field of PR.

\section{Results and Discussion}

\section{Three facets of PR activity}

As an interdisciplinary field of professional activity, PR is closely related to advertising, marketing, journalism, business, finance, education and other academic disciplines. PR councilors should thus be knowledgeable in marking, law, communication, culture studies, ecology, creating videos, writing texts including posting for the social networks. For PR expert it is essential to fulfill a double task: 1) to improve the company's reputation 2) to win the trust of the audience.

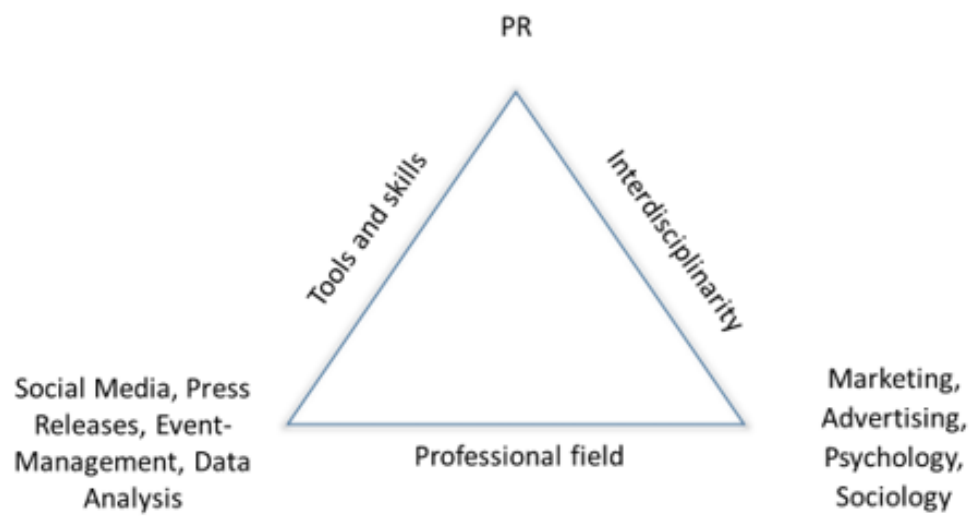

Figure 1. A Triangle presenting three facets of PR.

The three facets of PR include the professional field of communication, its multidisciplinarity and certain tools and skills, necessary to achieve the strategic goal of PR councilors in any sphere of activity: politics, business, medicine, education, sports and social sphere at large. Professional communication delivers workplace information by oral, written, visual and digital means. At present it is of primary importance, because failures of communication cause a lot of problems. Effective professional communication guarantees effortless transfer of ideas, facts, opinions, recommendations and choices. Practitioners of the PR industry single out the following features of professional communication: accuracy, clarity and brevity, distinctiveness, segmentation, continuity, internal and external fields, two-way traffic (symmetric communication) and multichannelity (Kukhnavets, 2018).
The suggested triangle illustrating the three facets of PR is also necessary for successful creation and promotion of the interests of the company by means of press releases. The professional field is the foundation of the communication knowledge of the occupational area. It dictates what particular tools should be used and skills (competences) should be developed, as every vocational sector is inseparably connected with different professional spheres, which explains the usage of interdisciplinary approach to PR discourse.

The vertices of the PR triangle in Figure 1. reflect the particularities of every discipline and field of knowledge. In one case, one vertex illustrates the complexity of PR discourse at the interdisciplinary level. For successful PR practice various things are involved: social media, press releases, event management, data 
analysis etc. Another vertex of the PR triangle deals with exact disciplines, necessary for understanding and accomplishment of the PR goal to inform the public and influence the choice. The third vertex symbolizes the theory and practice of the communicative sphere of public relation in a holistic vision.

PR experts use various communication techniques to inform the public and the companies. They are: preparation and dissemination of information materials, such as press releases, media kits, background stories, announcements and greetings. Event Management includes organizing briefings, press conferences, summits and journalists' gatherings. It entails writing and editing texts, commentaries and speeches as well as gatekeeping. Corporate newspaper has the function of informing the inner public and building a stronger brand. Special skills are required for creating and printing brochures, leaflets, posters and greeting cards.

\section{Axiological aspect of PR activity}

For PR discourse it is highly essential to emphasize the relevance of universal values which pertain to all the humanity as well culture specific values relevant for a particular nation or region. This aspect often becomes a crucial point in the course of PR experts' education (MinyarBeloroucheva et al., 2021). It lies in the scope of educators to instill moral and ethical principles in the future PR experts who will be responsible for influencing public opinion and making judgements.

It is necessary to say that values are determined by a paradigm and with every paradigm shift, humanity comes across with a new set of values pertaining to society.

The word 'value' entered the English language in 1300 meaning 'price equal to the intrinsic worth of a thing'. In the late $14^{\text {th }}$ century its meaning extended to mean 'degree to which something is useful or estimable'. The meaning comes from the Old French of the $13^{\text {th }}$ century noun 'value' 'worth, price, moral worth; standing, reputation'. It was used in the feminine form of past participle of valoir 'be worth', originating from Latin 'valere' - 'be strong, be well; be of value, be worth' dating back to Proto-Indo-European root 'wal-' - 'to be strong' (Harper, 2015). As it comes clear from the given definitions, originally the word 'value' included 'estimation' and 'valor' which are of primary importance for PR discourse. The two different meanings denoting tangible and intangible qualities within one word are interconnected and interdependent so that this creates a stable strong feature attributed to both of them. Estimation is connected with tangible things which have a certain material cost, while the intangible feature in linked with valor. It is defined in the etymological dictionary as 'value, worth', originating from the Old French word 'valor', 'valour', 'valor, moral worth, merit, courage, virtue' of the $12^{\text {th }}$ century. The meanings are attributed to Latin valorem (nominative valor) 'value, worth', which meant 'strength, valor' in Medieval Latin stemming from Latin valere 'be strong, be worth' coming from Proto-Indo-European root *wal- 'to be strong'. Later on in the $16^{\text {th }}$ century 'valor' got the meaning of 'courage' coming from Italian 'valore', which has the same Late Latin word. The Middle English word also acquired the meaning of 'worth or worthiness in respect of manly qualities' (Harper, 2015). In the course of the development of human society 'valor' got the meaning of 'social principle', which was attested in the $20^{\text {th }}$ century.

Originally valor was connected with the following human values: piety (pietas), fidelity (fides), seriousness (gravitas), firmness (constantia), united by the concept of virtus (virtue, valor), which combined military courage with the zealous performance of civil duty - the objectives of the Ancient Romans. The aforementioned values were traditionally understood as physical virtues. The etymological dictionary provides us with the following definition: virtue - in 1200 'vertu' meant 'moral life and conduct; a particular moral excellence', originally came from Anglo-French and Old French of the $10^{\text {th }}$ century 'vertu' with the meaning of 'force, strength, vigor; moral strength; qualities, abilities'. The word stems from Latin 'virtutem' (nominative 'virtus') meaning 'moral strength, high character, goodness; manliness; valor, bravery, courage (in war); excellence, worth'. In Proto-IndoEuropean the word was 'vir 'man' - the PIE root *wi-ro- 'man'. qualities' (Harper, 2015). A special meaning was attributed to 'virtue' in the Middle Ages and was connected with Christianity. The theocentric vision was manifested in such virtues as faith, hope and love. Biblical principles became the guidance for the human life. The values of the Renaissance are founded on the principles of humanism indicating the human to become the center of the world vision. The ideas of dignity, virtue and moral principles became most important for the human life to be later revisioned again when 


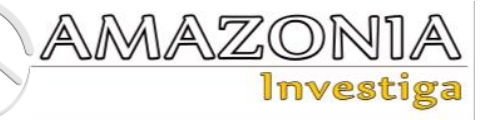

science took the upper hand in the worldview of the people.

In Modern Times among the moral ground rules were such general principles of morality as: humanism - recognition of a person as the highest value; altruism - selfless service to one's neighbor; charity - a compassionate and active love, expressed in a willingness to help everyone in need of something; collectivism - a conscious desire to promote the common good; rejection of individualism - the opposition of the individual to society, any sociality, and egoism - the preference of one's own interests to the interests of all others. These assumptions predetermined the development of contemporary values, which radically differ from the traditional ones. Moreover, some worldviews counteract the established and time-tested principles.

For the reason of modern values being varied and volatile and not universally accepted, PR discourse strives to harmonize the difference by addressing people adhering to different values of the present day. Press releases strive to bridge the gap existing between different generations, age, genders, social classes, races, and cultures bringing the people closer together. Instilling the general ideas of kindness, love, equality, mercy and empathy the copyrights aim to cover the widest audience possible to win their respect and trust.

In the pandemic time of 2020-2021 when the Procter and Gamble company, a leading producer of healthcare products, announced certain charity actions, including World Kindness Day. The following press release illustrates the actions of the company to support the older people separated from their families during the challenging period. This kindness is extended to support the people in need. For this purpose, the copyrights employ the following phrase:

In celebration of World Kindness Day, Ivory, known for providing a touch of love and kindness, is focused on spreading positivity with the launch of the brand's Acts of Gentle Kindness initiative. (P\&G News Releases, 2020).

In this press release the copyrights emphasize the support and care for senior citizens by using such words and phrases as 'gentle care', 'extra love and care', 'love and trust', 'stay warm', 'fun and entertainment', 'fun activities', 'comfort items', 'to help them feel safe and cozy', 'smiles on the faces of the seniors', to make happy', 'to have a positive impact on someone's day', 'family heritage and values'. Such lexical units as

'kindness', 'love', 'positivity', 'gentle' emanating 'tenderness' address the consumers. These words and phrases are used to combat negative emotions connected with the feelings of loneliness as well as the risk of illness, which can be detrimental to people's health and well-being. The positive emotions to be praised include love, joy, fun, entertainment, that bridge the generation gap. This press release teaches people to be kind to others by providing positive examples of the company's actions. It also illustrates the interdisciplinary approach in practice. Primarily, it is raw material for advertising, the words and phrases of the press release, the subject of linguistics, render the feelings, which are the prerogative of psychology the knowledge of which is necessary for successful marketing and development of society, which is studied by sociology, that corresponds to the right vertex of the PR triangle, pictured in Figure 1.

Universal values are traditionally perceived as a set of established beliefs and virtues. For the majority of people universal values include morality, aesthetic preference, human rights, human endeavor and social order (Schwartz, 1992). It should be pointed out, that a value can be considered a universal value if it has the same meaning for everyone. When universal values are used effectively in PR discourse, the professional texts take advantage of special persuasive means. The axiological approach helps creating a positive image of the whole company by informing the public of its credibility and reliability. Such company as Procter and Gambler in order to acquaint the customers closer with the company introduces its own values, which include integrity, leadership, ownership, passion for winning and trust $(\mathrm{P} \& \mathrm{G}$ Policies and Practices, 2021).

In other words, the company stresses its strife for victory and trust of the audience. It should be noted that such notions as leadership, dignity and trust although correlating with the Ancient Roman values are still valid at present. These values become of special relevance for the top managers and the officials of the company for whom the battlefields are the press releases through which they are trying to win the audience. Thus, relevant become the leadership and the passion for winning. The P\&G website introducers the leadership team to the customers in the following way:

Our leadership approach is distinctly $P \& G$. We set a clear, rigorous course for developing leaders and growth in every business and region, at every level. As a result, our diverse leadership 
team is shaping our future with an extensive range of knowledge, experience, and expertise to improve consumers' lives today and into the future (P\&G Leadership team, 2021).

Only most prominent and vigorous press releases, i.e. the winners, are able to persuade and win the audience by securing trust and respect. This goal is achieved by involving the audience in the company's inner circle. For this purpose, the copyrights employ personal and possessive pronouns 'we' and "our" in such phrases as 'We set a clear, rigorous course', 'Our leadership approach', 'our diverse leadership team', 'our future'. The feeling of intimate relations with the customers, created in the press release, allows the company to build trust and respect towards its actions.

Among other values is integrity which is manifested in bringing the people together, as the aforementioned example of the Ivory brand to help the senior citizens to be happy. The same value can also be seen in different initiatives of the company and other press releases, which integrate routine human life and scientific and technological achievements. The progress of science plays a crucial role in daily pursuits and work. Man entered space and certain companies offer their service to support this industry by facilitating chores in space. Procter and Gamble's brand Tide introduces innovative solutions to be implemented on earth and in space in the following press release:

The Procter \& Gamble laundry brand partners with NASA in a Space Act Agreement to explore how to efficiently clean astronauts' clothing in resource-constrained environments, including the Artemis Moon missions and future Mars missions.

TORONTO - (BUSINESS WIRE) - Tide ${ }^{\circledR}$ has signed a Space Act Agreement with NASA to help in the development of laundry detergent solutions and technology development in space. Under the agreement, NASA may test and study Tide cleaning solutions in space. The study could have potential on-planet implications like innovative solutions for resource and environmental challenges on Earth. Aligning with Tide's decade-long sustainability commitment, Ambition 2030, Tide will strive to bring offplanet learnings back to everyday consumer products.

... The limited cargo capacity makes the practice of replenishing the clothing supply challenging for deep space missions, such as Artemis Moon missions and a crewed roundtrip Mars mission.

In addition to testing onboard the ISS National Lab, NASA and Tide researchers may study how an innovative combined washing and drying unit utilizing the special-formulated detergent could potentially be integrated into planetary habitats that may be used for the Artemis Moon and Mars missions under low-gravity surface conditions. There are also a unique set of challenges that present themselves for a crewed Mars mission. Future missions to and from Mars expect to span multiple years, and these long-duration flights will require laundry solutions designed for extreme space-based environments and varying gravity conditions. (P\&G News Releases, 2021).

This press release demonstrates common needs and day-to-day activities which are characteristic of life on earth and in space. By issuing this initiative Procter and Gamble shows dedication to scientific progress and innovative practices. The copyrights indicate the company's flexibility and readiness to change:

We are eager to apply our learnings from our partnerships with NASA and the ISS National Lab to Tide on Earth, developing a low-resourceuse laundry solution for everyday use while meeting consumer demand for more sustainable products (P\&G News Releases, 2021).

The copyrights demonstrate aspiration for sustainable development and innovative practices to be implemented in their products. The authors indicate the future is now, which integrates the present and the future.

Integrity is the main concept of individual and common ownership, because at present common ownership is important for every individual, on the one hand. On the other hand, it is well known that it is absolutely impossible for one person to rule individually on the planet. These values dealing with integrity, unification and commonwealth become of special relevance in the contexts of environmental protection and pandemic resistance.

The following excerpts of press releases illustrate the company's call for environmental protection:

Humanity has reached a pivotal point where on one hand, we're on the exciting cusp of space colonization, and on the other, facing a critical period where action must be taken now to save the planet we all call home (P\&G News Releases, 2021). 


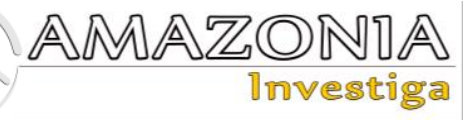

Integrity comes also in the form of regular collaboration of consumer goods companies and cutting edge science and technology laboratories, as it is claimed in the following statement:

The ISS National Lab is excited to work with the $P \& G$ team once again as they push the limits of their research and development onboard the orbiting laboratory (P\&G News Releases, 2021).

As copyrights claim, such partnerships allow the development of technologies, not achievable on our planet: 'through private-sector utilization of the space station, companies like $P \& G$ can conduct investigations in ways not possible on Earth to develop new consumer products, enhance existing products, and better understand processes that further business models both on the ground and in low Earth orbit' (P\&G News Releases, 2021). That is why the excitement of the ISS National Lab to work with the P\&G team is stressed in the cited press release.

The P\&G company in its development mission always sets new goals and strives to achieve new purposes. Thus, amid COVID-19 pandemic this company does not only promote the ready-made products connected with fighting viruses in general, but also finds new solutions and works out new products counteracting effectively against the new threat:

CINCINNATI \& CAMBRIDGE, Mass.-(BUSINESS WIRE) - Procter \& Gamble $(P \& G)$ is licensing its novel nasal swab to Rhinostics to launch and bring to the clinical laboratory market. $P \& G$ developed the swab as part of its commitment to help communities address supply shortages and to bring creative solutions to bear on the challenges facing laboratories and supply chains during the COVID-19 pandemic (P\&G News Releases, 2021).

The P\&G company helps the families to be safe during the time of pandemic by developing new products and conducting independent expert evaluation:

In accordance with Health Canada's guidelines, Microban 24 Sanitizing Spray has been tested by a third-party lab, and was shown to kill SARSCoV-2 in five minutes. Microban 24 Sanitizing Spray is the second product in the brand's lineup that provides an initial kill of the virus, when used as directed. Microban 24 Multi-Purpose Cleaner was also approved by Health Canada last month (Weekes, Durieu, 2021).
All the mentioned examples reflect the five main values of integrity, leadership, ownership, passion for winning and trust, adopted by the P\&G company and which are transmitted to the general public and millions of its consumers.

It should be noted, that values have come to professional PR discourse analysis from other humanitarian fields of knowledge, which emphasizes interdisciplinarity of the modern approach to PR theory and practice. Originally axiology was shaped as a branch of philosophy, later to be borrowed by psychology, sociology and public relations. Philosophical ideas of good and bad, beautiful and ugly, as well as social acceptance of certain principles and modes of conducts are taken advantage of in the sphere of PR. Linguistics studies verbalization of mental ideas, stressing the importance of language as a means of intercultural communication. Cognitive linguistics takes into account persuasion and suggestion of the people by using special linguistic means and their link to mental space. Interdisciplinarity in this case is crucial for paramount investigation of the axiological aspect of PR discourse.

Language is both a cultural instrument and one of its manifestations. The function of the language is to preserve culture and transfer it from generation to generation, playing a vital role in the personality development, reflection of national character, people, and nation (TerMinasova, 2000). We speak of the mental representations realized in language in the framework of cognitive linguistics. Scholars have claimed interdisciplinarity to be the essential premises for the comprehensive coverage of research in the cognitive paradigm (Zabotkina \& Boyarskaya, 2017). Axiological aspect of interdisciplinary study of PR discourse includes distinguishing positively connotative verbalized vallues, such as 'integrity', 'leadership', 'ownership, 'passion for winning' and 'trust'. They are necessary to create a positive image of the company and instill confidence in the audience.

\section{Conclusions}

The present research is the result of PR discourse analysis from the interdisciplinary point of view with special attention to linguistics. In the process of study certain linguistic particularities of PR discourse have been singled out and analyzed. It has been established that linguistic and stylistic aspects represent the interdisciplinary core of PR discourse, which is manifested in one of the three facets of PR 
activity, including the professionally oriented activity, knowledgeable PR experts as well as communication tools and skills. It was also found out that PR discourse is permeated by axiological statements. It has been established that by PR instruments international companies achieve their goals by instilling corporate values within the general public, such as integrity, leadership, ownership, passion for winning and trust.

In general, PR discourse implying anthropocentric-communicative interpretation contributes to the theory and practice of interdisciplinary studies which become the main feature of the 21 st century.

\section{Bibliographic references}

Adolphsen, M. (2014) Public discourse beyond national borders. Communication Strategies of Governments and NGOs. Springer VS, Wiesbaden. https://doi.org/10.1007/978-3658-05504-2_2

Berger, B. R. (2011). The Globalization of PR Education? Ipra. https://www.ipra.org/news/itle/theglobalization-of-pr-education/

Bernays, E. (1923). Crystallizing Public Opinion/ E. Bernays. New York: Liveright Publishing Corporation, 219 p.

Black, S. (1989). Introduction to Public Relations. Modina Press in conjunction with the International Public Relations Association.

Fairclough, N. (2000). Discourse, social theory and social research: the discourse of welfare reform. Journal of Sociolinguistics, 4(2), 163-195.

Grunig, J.E. (1984) Managing Public Relations / J.E. Grunig. T. Hult, Rinehart\&Winston. Recovered from: https://www.researchgate.net/publication/32 2802009_Managing_Public_Relations

Guerreiro, J.A. (2016). Interdisciplinary Research in Social Sciences: a two way process? /Proceedings of the International Congress on Interdisciplinarity in Social and Human Sciences. Faro. CIEO - Research Centre for Spatial and Organizational Dynamics. University of Algarve. ULR: https://www.researchgate.net/publication/30 5765986_Interdisciplinary_Research_in_Soc ial_Sciences_a_two_way_process

Harlow, R. F. (1976). Building a Public Relations Definition/Public Relations Review. Winter, 2(4).

Harper, D. R. (2015). Online Etymology Dictionary. Recovered from: https://www.etymonline.com/ (accessed 12.07.2021)

Heaney, K. \& Rebolini, A. (2017). Public Relations. An excerpt. Medium. available at URL: https://medium.com/thehairpin/public-relations-d3741e9cdb7e (accessed 30.04.2021)

Hoffmann-Riem, H., Hadorn, G.H., Biber-Klemm, S., Grossenbacher-Mansuy, W., Joye, D., Pohl, CH., Wiesmann, U., ... \& Zemp, E. (2008). The Emergence of Transdisciplinarity as a Form of Research. Handbook of Transdisciplinary Research, 19-39. Berlin: Springer. DOI: 10.1007/978-14020-6699-3_2

IPRA Goldpapers (1982). A Model for Public Relations Education for Professional Practice. In Gold Paper No. 4 (p. 25) International Public Relations Association.

Jessop, B. \& Sum, N. (2001) Pre-disciplinary and post-disciplinary perspectives. New Political Economy, 6(1), pp. 89-101.

Kubryakova, E.S. (1981). Types of language values. M.: Nauka, 200p. (in Russian)

Kukhnavets, P. (2018) Why is Professional Communication Critical for Any Business? Hygger. Recovered from: https://hygger.io/blog/professionalcommunication-critical-business (accessed 30.04.2021)

Minyar-Beloroucheva, A., Sergienko, P., Vishnyakova, E. \& Vishnyakova, O. (2020). New linguiodidactic challenges in teaching professionally oriented English as referred to PR-education. European Proceedings of Social and Behavioural Sciences, Vol. 97, no. TILT. DOI: 10.15405/epsbs.2020.12.02.72

Minyar-Beloroucheva, A.P., Sergienko, P.I., Vishnyakova, O.D., Vishnyakova, E.A. \& Anossova O.G. (2021). Axiological approach to developing spirituality and morality in the process of L2 PR education/ SHS Web of Conferences. no. 103. https://doi.org/10.1051/shsconf/2021103010 24

P\&G Leadership team (2021). Leadership. A team with a future in mind. Recovered from: https://us.pg.com/leadership-team/ (accessed 18.07.2021)

P\&G Nwes Releases (2021). P\&G Partners With Rhinostics to Take Innovative Nasal Swab to Market to Improve Speed of COVID-19 Testing. Recovered from: https://news.pg.com/news-releases/newsdetails/2021/PG-Partners-With-Rhinosticsto-Take-Innovative-Nasal-Swab-to-Marketto-Improve-Speed-of-COVID-19-

Testing/default.aspx (accessed 18.07.2021) 


\section{AMAZOND孞 \\ lกvestiำ}

P\&G Policies and Practices. (2021). Recovered from: https://us.pg.com/policies-andpractices/purpose-values-and-principles/ (accessed 30.04.2021)

P\&G News Releases (2021). Tide to Design First Laundry Detergent for Space, to Begin Stain Removal Testing on International Space Station in 2022. Recovered from: https://news.pg.com/news-releases/newsdetails/2021/Tide-to-Design-First-LaundryDetergent-for-Space-To-Begin-StainRemoval-Testing-on-International-SpaceStation-in-2022/default.aspx (accessed 18.07.2021)

P\&G News Releases. (2020). Ivory Celebrates World Kindness Day Through Initiative Aimed at Spreading Positivity. Recovered from: https://news.pg.com/newsreleases/news-details/2020/Ivory-CelebratesWorld-Kindness-Day-Through-InitiativeAimed-at-Spreading-Positivity/default.aspx (accessed 18.07.2021)

Petrov, K.D. \& Wilson, J. A.J. (2016). The Little Black Book of PR: Mastering Public Relations in a Changing World. P World. 205 p. Available at: https://www.amazon.com/Little-Black-

Book-Mastering-Relationsebook/dp/B01LXNM29Y

Rosenberg, A. (2021). A Modern Guide to Public Relations: Unveiling the Mystery of PR. PRSA URL: https://www.prsa.org/about/allabout-pr

Schwartz, S. H. (1992). Universals in the Content and Structure of Values: Theory and Empirical Tests in 20 Countries/ In M. Zanna (ed.), Advances in Experimental Social Psychology (Vol. 25). New York: Academic Press: 1-65.

Sergienko, P., Minyar-Beloroucheva, A., Vishnyakova, O., \& Vishnyakova, E. (2021). Academic conferences in professionally oriented language acquisition by public relations undergraduates. Amazonia Investiga, $\quad 10(42), \quad 69-79$. https://doi.org/10.34069/AI/2021.42.06.7
Stahl, S. (2018). The Art \& Craft of PR: Creating the Mindset and Skills to Succeed in Public Relations Today. LID Publishing. 128p. Available at: https://www.goodreads.com/book/show/367 02210-the-art-craft-of-pr

Tanji, M. \& Broudy, D. (2017). Critical Discourse Analysis of Public Relations. In book: Okinawa Under Occupation, pp. 13-29. DOI: 10.1007/978-981-10-5598-0_2

Ter-Minasova, S.G. (2000). Language and intercultural communication: textbook. M.: Slovo. (in Russian). Recovered from: https://www.studmed.ru/view/ter-minasovasg-yazyk-i-mezhkulturnayakommunikaciya_5e7d359e75c.html

Vishnyakova, O., Minyar-Beloroucheva, A., Sergienko, P. \& Vishnyakova, E. (2020). Harmonizing different cognitive styles through reading, in 5th International eConference on Studies in Humanities and Social Sciences: Conference Proceedings, 24-28 June 2020, Belgrade, Serbia, 17-30 (2020). https://doi.org/10.32591/coas.econf. $05.02017 \mathrm{v}$

Weekes, R., \& Durieu, C. (2021) Finance Yahoo. Recovered from: https://finance.yahoo.com/news/microban24-sanitizing-spray-approved140000973.html (accessed 26.07.2021)

Weiss, G. \& Wodak, R. (2003). Critical Discourse Analysis Theory and Interdisciplinarity. Palgrave Macmillan Ltd.

Wolstenholme, S. (Ed.). (2013). Introduction to Public Relation. Pearson Education Limited. 252p. Available at: https://www.amazon.com/IntroductionPublic-Relations-SueWolstenholme/dp/0273750984\#detailBullets _feature_div

Zabotkina, V. \& Boyarskaya, E. (2017). On the challenge of polysemy in contemporary cognitive research: What is conscious and what is unconscious. Psychology in Russia, 10(3), 28-39. https://doi.org/10.11621/pir.2017.0302. 